\title{
Analisis Interaksi Siswa pada Aktivitas Diskusi Kelompok dalam Pembelajaran Matematika Secara Daring
}

\author{
Aulia Nadia Sari $^{1}$, Subanji ${ }^{2}$, Sisworo $^{2}$ \\ 1,2,3 Program Studi S2 Pendidikan Matematika, Fakultas Matematika dan Ilmu Pengetahuan Alam, Universitas Negeri Malang, \\ Jl. Semarang No 5, Sumbersari, Kec. Lowokwaru, Kota Malang Indonesia \\ aulianadiasari@gmail.com
}

\begin{abstract}
The Covid-19 has entered and attacked Indonesia since early 2020. This pandemic has had impact on society, especially in education. School must be closed, and learning is done online. However, the atmosphere of student interaction is important for meaningful learning. The objective of this study is to describe studets interaction in group discussion activities in online mathematics learning. The sample of this study is students second grade of SMAN 1 Giri Banyuwangi. The subject of this study is three group of students MIA 6 each group consist of five students. The method of this study is qualitative method with narrative approach. Positioning theory shows how students determine positions based on conversation. In addition, the storyline can also be seen from how students negotiate. The result of the study stated that students performed various movements in discussion process. The number of knowledge exchange more than the number of action exchange. The expert and novice can be clearly identified, while the facilitator cannot be clearly identified. The students often discuss about resources and products of the task. Based on the direction of the challenge, interactions can be grouped into two different forms, such that complex forms and simple form. The complex forms consist of two directions such as self challenge and challenge of others. The simple form consists of one direction that is self challenge.
\end{abstract}

Keywords: Interaction, Learning, Online

\begin{abstract}
Abstrak
Pandemi Covid-19 masuk dan menyerang Indonesia sejak awal 2020. Pandemi ini memberikan dampak kepada masyarakat terutama bidang Pendidikan. Sekolah ditutup dan pembelajaran dilakukan secara online. Meskipun demikian, penciptaan suasana interaksi siswa menjadi hal yang penting untuk pembeljaran bermakna. Penelitian ini bertujuan untuk mendeskripsikan interaksi siswa pada aktivitas diskusi kelompok dalam pembelajaran matematika secara daing. Sampel penelitian ini adalah siswa kelas XI SMAN 1 Giri Banyuwangi. Subjek penelitian adalah tiga kelompok siswa kelas XI MIA 6 dengan masing-masing kelompok terdiri dari 5 siswa. Metode penelitian yang digunakan adalah metode penelitian kualitatif dengan pendekatan naratif. Teori pemosisian menunjukkan bagaimana siswa menentukan posisi berdasarkan percakapan. Selain itu alur cerita juga dapat dilihat dari bagaimana siswa melakukan negosiasi. Hasil penelitian menyatakan bahwa siswa melakukan berbagai gerakan pada saat berinteraksi. Banyaknya pertukaran pengetahuan lebih dari banyaknya pertukaran tindakan. Ahli dan pemula dapat diidentifikasi dengan jelas, sedangkan fasilitator tidak dapat diidentifikasi dengan jelas. Objek yang sering didiskusikan terkait dengan produk dan sumber daya. Berdasarkan arah tantangan, interaksi dapat dikelompokkan dalam dua bentuk yang berbeda yaitu bentuk kompleks dan bentuk sederhana. Bentuk kompleks terdiri dari dua arah yaitu tantangan diri sendiri dan tantangan kepada orang lain. Bentuk sederhana terdiri dari satu arah tantangan, yaitu tantangan diri sendiri.
\end{abstract}

Kata kunci: Interaksi, Pembelajaran, Daring

Copyright (c) 2021 Aulia Nadia Sari, Subanji, Sisworo

Corresponding author: Aulia Nadia Sari

Email Address: aulianadiasari@gmail.com (Jl. Semarang No 5, Sumbersari, Kec. Lowokwaru, Kota Malang Indonesia) Received 26 July 2021, Accepted 29 July 2021, Published 10 August 2021

\section{PENDAHULUAN}

Penciptaan suasana interaksi antar siswa sangat penting untuk pembelajaran yang bermakna. Sebagaimana hasil suatu penelitian, bahwa dengan adanya kolaborasi antar siswa, penyelesaian masalah lebih kondusif daripada siswa bekerja secara mandiri (Azmitia, 1988). Selain itu, pembelajaran yang melibatkan interaksi dapat digunakan untuk memahami masalah yang terjadi di kelas. Pentingnya interaksi diperlukan guru untuk mendesain rencana pembelajaran yang memungkinkan untuk mengatasi masalah 
tersebut (Cobb, Yackel, \& Wood, 1992). Proses interaksi yang sedang berlangsung juga dapat digunakan untuk melihat penalaran siswa (Cobb, Stephan, McClain, Gravemeijer, 2001)

Berbagai peneliti telah melakukan penelitian terkait dengan interaksi siswa pada pembelajaran matematika. Ditemukan bahwa interaksi siswa pada kelompok kecil dapat membatu siswa mendapatkan pemahaman konseptual yang lebih banyak (Hunter \& Anthony, 2014). Peneliti lain menemukan bahwa interaksi sosial siswa mempengaruhi prestasi belajar siswa SMA pada mata pelajaran matematika (Apriliyanto, Saputro, \& Riyadi, 2018). Selain itu, pola Interaksi siswa secara signifikan mempengaruhi hasil belajar matematika siswa sekolah menengah (Katiambo, Mutsotso, \& Wasike, 2019)

Interaksi adalah aksi timbal balik (Pusat Bahasa, 2008). Interaksi (sosial) adalah situasi perilaku manusia yang secara sadar dikondisikan dan mempengaruhi perilaku manusia lain dan sebaliknya (Turner, 1988). Dengan demikian, interaksi adalah hubungan timbal balik antar individu untuk mendapatkan tujuan tertentu. Seseorang melakukan interaksi dengan orang lain karena movitasi tertentu. Menurut Mead, roses interaksi terjadi dalam tiga tahap, pertama seseorang mengrimkan sinyal pada orang lain, kedua orang lain menerima sinyal dan merespon, dan ketiga orang pertama menerima respon dengan melakukan perubahan perilaku (Turner, 1988).

Interaksi siswa pada aktivitas diskusi kelompok dapat diidentifikasi melalui teori pemosisian dan sistem negosiasi. Kata 'posisi' berperan dalam menggambarkan bagaimana seseorang berinteraksi dengan orang lain (Herbel-Eisenmann, Wagner, Johnson, Suh, \& Figueras, 2015). Pada setiap interaksi, siswa dapat memposisikan dirinya sendiri atau diposisikan oleh siswa lain (DeJarnette \& González, 2015). Posisi tersebut diperoleh bukan karena pilihan, akan tetapi dapat diamati pada proses interaksi. Posisi setiap siswa bersifat sementara, terkait dengan jenis tindakan yang dilakukan dan sifatnya timbal balik. Selain posisi, pertimbangan lain untuk menganalisis tindakan komunikasi yaitu alur cerita. Tiga jenis posisi yang dapat diperankan oleh masing-asing siswa dalam proses interaksi yaitu ahli, pemula, dan fasilitator. Siswa yang diposisikan sebagai ahli sering diberikan pertanyaan dari siswa lain, sering diberikan wewenang untuk memutuskan apakah pekerjaannya benar atau salah. Siswa yang diposisikan sebagai pemula sering bertanya kepada siswa ahli, sering diperintahkan oleh siswa lain, kadang-kadang mempertanyakan pendapat siswa ahli. Siswa yang diposisikan sebagai fasilitator sering mengorganisasikan kegiatan kelompok dan menumbuhkan partisipasi anggota kelompok. Siswa fasilitator mendorong anggota kelompok untuk berperan aktif dalam penyelesaian masalah dalam kelompok. Teori pemosisian menyatakan bahwa posisi setiap individu bersifat dinamis (McVee, Silvestri, Barrett, \& Haq, 2019); (Zelle, 2009) . Individu bermain peran dalam suatu posisi, mengubah posisi dan memposisikan diri yang sifatnya sementara.

Sistem negosiasi digunakan untuk mempelajari bagaimana siswa menentukan posisi berdasarkan percakapan. Interaksi yang dilakukan seseorang dalam dialog dapat dimulai dengan membuat pernyataan, mengajukan pertanyaan, menyediakan barang atau jasa, atau meminta barang atau jasa (DeJarnette \& Gonzalez, 2015). Pada suatu interaksi, pertukaran posisi yang terjadi pada diri sendiri juga mengakibatkan terjadinya pertukaran posisi pada orang lain. Konten dialog pada interaksi dianalisis menggunakan sistem negosiasi. Selain itu, sistem negosiasi juga berperan dalam menganalisis bagaimana peran percakapan dalam memposisikan 
pembicara dan responden selama berlangsungnya interaksi. Konten dialog diamati dari komponen pada tugas matematika, yang berkaitan dengan produk, sumber daya dan operasi. Produk yaitu solusi atau penyelesaian masalah yang sedang dipecahkan. Sumber daya yaitu informasi-informasi yang dibutuhkan atau yang diberikan dalam memecahkan masalah. Operasi yaitu proses hitung untuk memecahkan masalah. Pada sistem negosiasi, dua jenis pertukaran yang dipertimbangkan yaitu pertukaran pengetahuan (K: Knowledge) dan pertukaran tindakan (A: Action). Siswa yang berinteraksi dapat dibedakan sebagai siapa yang tahu sebagai aktor utama dan siapa yang tahu sebagai aktor sekunder.

Pandemi covid-19 mulai masuk dan menyebar di wilayah Indonesia sejak awal 2020. Datangnya pandemi ini memberikan dampak kepada masyarakat, terutama bidang pendidikan. Sekolah harus ditutup dan pembelajaran dilakukan secara online (Aji, 2020). Hal tersebut sudah ditetapkan oleh pemerintah pada surat edaran terkait dengan pelaksanaan pembelajaran dalam keadaan darurat penyebaran virus covid-19 (Kementerian Pendidikan dan Kebudayaan, 2020). Sehingga, pembelajaran daring telah dilakukan di berbagai jenjang pendidikan sekolah dan perguruan tinggi sejak adanya penetapan tersebut. Sebanyak $23,3 \%$ siswa menilai sangat efektif dan $46,7 \%$ siswa menilai efektif pada pembelajaran matematika yang dilakukan secara online (Mustakim, 2020). Akan tetapi, nilai siswa yang mengikuti pembelajaran online tidak lebih tinggi dari nilai siswa yang mengikuti pembelajaran tatap muka (Francis, Wormington, \& Hulleman, 2019).

Berbagai peneliti telah melakukan penelitian terkait dengan pembelajaran dalam jaringan. Suatu penelitian telah dilakukan terkait dengan analisis kesulitan mahasiswa pendidikan matematika dalam pembelajaran daring. Hasil penelitian tersebut menunjukkan bahwa kesulitan mahasiswa tergolong dalam tiga kategori, yaitu kesulitan teknis, kesulitan adaptasi dan ketidaksiapan pengajar (Annur \& Hermansyah, 2020). Penelitian lain dilakukan terkait dengan proses pembelajaran matematika di sekolah dasar dalam pembelajaran daring. Hasil penelitian menunjukkan bahwa proses pembelajaran siswa secara daring masih melibatkan peran serta orang tua siswa dalam pengambilan tugas putra-putrinya ke sekolah (Wiryanto, 2020). Selain itu, hasil penelitian lain juga menyatakan bahwa pembelajaran matematika daring tidak cukup efektif (Kusumaningrum \& Wijayanto, 2020). Hal tersebut didukung dengan fakta hasil penelitian yang telah disebutkan bahwa perkuliahan sering terkendala jaringan internet sehingga aktivitas perkuliahan tidak lancar. Akibatnya, materi yang disampaikan oleh bapak/ibu dosen tidak dapat diterima dan dipahami dengan baik. Selain itu, pembelajara online diperlukan keterampilan dan pengetahuan tentang cara menggunakan perangkat online; perlu mempunyai alat teknologi yang diperlukan sebagai fasilitas berinteraksi secara online; dan koneksi yang baik (Mulenga \& Marbán, 2020).

Berdasarkan uraian tersebut, siswa sangat memungkinkan untuk melakukan berbagai interaksi pada pembelajaran matematika luar jaringan (tatap muka). Akan tetapi dengan adanya pandemi Covid-19 ini mengakibatkan pembelajaran dilakukan secara daring. Oleh karena itu, penelitian ini perlu dilakukan untuk mendapatkan hasil belajar yang lebih baik pada pembelajaran matematika daring. Melalui penelitian ini, guru bisa mempertimbangkan heterogenitas kemampuan siswa dalam membentuk kelompok. Sehingga interaksi yang terjadi pada kelompok dapat diotimalkan untuk mencapai tujuan pembelajaran. Selain itu, guru juga bisa mengarahkan siswa untuk menyadari potensi yang dimiliki siswa terkait dengan perannya dalam diskusi 
kelompok. Sehingga interaksi yang terjadi mudah diarahkan dan dapat meningkatkan hasil belajar. Dengan demikian, bagaimana interaksi siswa yang terjadi pada pembelajaran matematika dalam jaringan? Oleh karena itu penelitian ini perlu dibahas dan dikaji lebih lanjut untuk mengetahui interaksi siswa yang terjadi pada pembelajaran matematika secara daring.

\section{METODE}

Penelitian ini bertujuan untuk menganalisis interaksi siswa pada aktivitas diskusi kelompok dalam pembelajaran matematika secara daring. Metode penelitian yang digunakan adalah metode penelitian kualitatif dan pendekatan naratif (diagram alir plaksanaan penelitian disajikan pada Gambar 1). Fenomena yang dialami subjek penelitian dipahami melalui penelitian kualitiatif. Kronologi suatu peristiwa yang dialami subjek dijelaskan melalui pendekatan naratif. Sebanyak 32 siswa terdistribusi ke dalam 6 kelompok. Tiga kelompok dipilih sebagai subjek peneltian. Pembelajaran matematika dilakukan secara daring melalui google meet dan whatsapp. diskusi kelompok dilakukan melalui pesan grup whatsapp. Interaksi siswa diidentifikasi berdasarkan percakapan pada pesan grup whatsapp. percakapan tersebut menentukan bagaimana siswa menentukan posisi dan bagaimana siswa melakukan langkah negosiasi. Pedoman negosiasi untuk mengidentifikasi interaksi siswa yang ditinjau berdasarkan pertukaran pengetahuan dan pertukaran tindakan disajikan pada Tabel 1. Pedoman pemosisian untuk mengetahui pola interaksi siswa dalam kelompok disajikan pada Tabel 2.

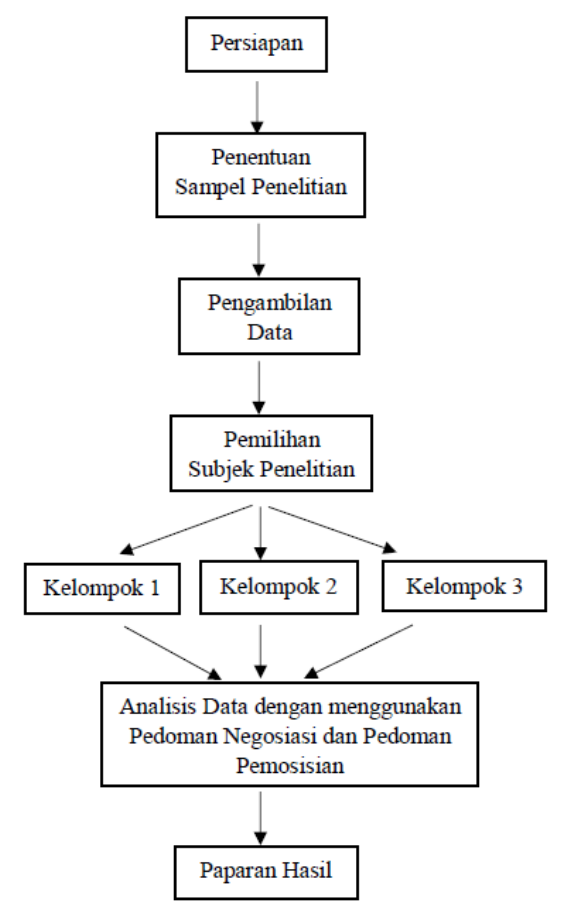

Gambar 1 Langkah Pelaksanaan Penelitian

Berdasarkan hasil survey, smua siswa di kelas XI 6 MIPA SMAN 1 Giri Banyuwangi mempunyai handphone pribadi dan $90 \%$ siswa mempunyai laptop/komputer. Pembelajaran daring membutuhkan fasilitas pendukung seperti handphone, laptop/computer (Handarini \& Wulandari, 2020). Dengan demikian 
sebagian besar siswa mempunyai fasilitas yang cukup untuk mengikuti pembelajaran daring. Selain itu, 75\% siswa dapat terkoneksi dengan jaringan wifi di rumah masing-masing dan sisanya hanya mengandalkan paket internet dari kartu perdana pada handphone masing-masing. Selain itu, berdasarkan hasil survey juga ditemukan beberapa kendala utama yang sering dilami oleh siswa saat pembelajaran daring. Kendala yang dialami siswa diantaranya yaitu tidak bisa fokus karena di rumah juga membantu ibu mengerjakan pekerjaan rumah; kehabisan kuota internet di waktu yang kurang tepat; sinyal tidak lancar; susah memahami penjelasan guru secara daring; dan aplikasi yang digunakan pada saat pembelajaran terkadang eror. Jaringan internet merupakan kendala utama dalam proses pembelajaran (Giatman, Siswati, \& Basri, 2020). Dengan demikian, jaringan internet yang sulit dijangkau mengakibatkan pembelajaran menjadi tidak lancar (Kusumaningrum \& Wijayanto, 2020).

Berbagai uraian kendala yang dialami siswa, bahwa sebenarnya $37,5 \%$ siswa tidak setuju apabila pembelajaran dilaksanakan secara daring. Meskipun demikian, siswa mengakui bahwa mereka tetap mengikuti pembelajaran daring dengan berbagai alasan. Alasan-alasan utama yang diakui siswa diantaranya yaitu kewajiban dalam mengikuti pembelajaran; kebutuhan untuk menimba ilmu; sebagai paksaan karena tidak dimungkinkan untuk melakukan pembelajaran tatap muka; dan tidak ingin ketinggalan materi karena materi pembelajaran sifatnya berkesinambungan. Dengan demikian, meskipun terdapat berbagai kendala yang dialami masing-masing siswa, semua siswa terfasilitasi untuk mengikuti pembelajaran daring. Penelitian ini dilakukan pada siswa yang mempunya fasilitas dalam mengikuti pembelajaran secara daring.

Tabel 1. Pedoman Pegerakan Siswa pada saat Diskusi Kelompok

\begin{tabular}{|l|l|l|}
\hline \multicolumn{1}{|c|}{ Pergerakan } & \multicolumn{1}{|c|}{ Pedoman } & \multicolumn{1}{c|}{ Simbol } \\
\hline $\begin{array}{l}\text { Pemberian } \\
\text { informasi }\end{array}$ & Siswa membuat pernyataan untuk memberikan informasi & $\begin{array}{l}\text { K1 (Prior } \\
\text { knowledge) }\end{array}$ \\
\hline $\begin{array}{l}\text { Pemberian } \\
\text { informasi tambahan }\end{array}$ & Siswa memberikan informasi tambahan dari informasi K1 & K1+ \\
\hline Pemberian stimulus & $\begin{array}{l}\text { Siswa menunda untuk memberikan informasi, siswa } \\
\text { meminta konfirmasi dari saran yang diajukan }\end{array}$ & dK1 \\
\hline Mengulangi K1 & Siswa menyatakan ulang informasi dari K1 & rtK1 (repeat K1) \\
\hline $\begin{array}{l}\text { Permintaan } \\
\text { informasi }\end{array}$ & Siswa mengajukan pertanyaan untuk meminta informasi & $\begin{array}{l}\text { K2 (Secondary } \\
\text { knowledge) }\end{array}$ \\
\hline $\begin{array}{l}\text { Pemberian respon } \\
\text { untuk K1 }\end{array}$ & $\begin{array}{l}\text { Siswa memberikan respon terhadap informasi K1 sebagai } \\
\text { tindak lanjut dari K2 }\end{array}$ & rK2 (response K1) \\
\hline $\begin{array}{l}\text { Melakukan } \\
\text { Tindakan }\end{array}$ & Siswa melakukan tindakan tanpa adanya permintaan & A1 (prior actor) \\
\hline Mengajukan diri & Siswa merekomendasikan diri untuk melakukan tindakan & dA1 \\
\hline $\begin{array}{l}\text { Permintaan } \\
\text { tindakan }\end{array}$ & $\begin{array}{l}\text { Siswa meminta orang lain untuk melakukan tindakan, } \\
\text { siswa bertanya terkait dengan sudah atau belum dalam } \\
\text { mengerjakan suatu tugas, }\end{array}$ & $\begin{array}{l}\text { A2 (secondary } \\
\text { Actor) }\end{array}$ \\
\hline Respon untuk A2 & Siswa memberikan respon lanjutan untuk A2 & rA2 (response A2) \\
\hline $\begin{array}{l}\text { Menantang orang } \\
\text { lain }\end{array}$ & $\begin{array}{l}\text { Siswa meragukan saran yang diajukan sehingga siswa } \\
\text { meminta pembuktian atau penjelasan dari saran tersebut }\end{array}$ & Ch (Challenge) \\
\hline $\begin{array}{l}\text { Menantang diri } \\
\text { sendiri }\end{array}$ & $\begin{array}{l}\text { Siswa mengungkapkan adanya keraguan dari saran yang } \\
\text { diajukan }\end{array}$ & sCh \\
\hline $\begin{array}{l}\text { Pemberian respon } \\
\text { untuk Ch }\end{array}$ & Siswa memberikan penjelasan terhadap tantangan Ch & $\begin{array}{l}\text { rCh (response of } \\
\text { Challenge) }\end{array}$ \\
\hline
\end{tabular}


Analisis Interaksi Siswa pada Aktivitas Diskusi Kelompok dalam Pembelajaran Matematika Secara Daring, Aulia Nadia Sari, Subanji, Sisworo ${ }^{2}$

\begin{tabular}{|l|l|l|}
\hline $\begin{array}{l}\text { Pembatalan } \\
\text { tantangan }\end{array}$ & Siswa membatalkan untuk meminta pejelasan atau bukti & $\mathrm{xCh}$ \\
\hline $\begin{array}{l}\text { Permintaan } \\
\text { Klarifikasi }\end{array}$ & Siswa meminta kepastian dari informasi yang diterima & Clq (Clarification) \\
\hline $\begin{array}{l}\text { Pemberian respon } \\
\text { Clq }\end{array}$ & $\begin{array}{l}\text { Siswa memberikan kepastian dari kebenaran informasi } \\
\text { yang diterima }\end{array}$ & $\mathrm{rClq}$ \\
\hline $\begin{array}{l}\text { Pemberian respon } \\
\text { bingung }\end{array}$ & $\begin{array}{l}\text { Siswa mengungkapkan bahwa dia tidak memahami } \\
\text { informasi }\end{array}$ & $?$ \\
\hline $\begin{array}{l}\text { Pemberian kontrol } \\
\text { aktivitas diskusi }\end{array}$ & $\begin{array}{l}\text { Siswa mengingatkan waktu hampir selesai, siswa bertanya } \\
\text { diskusi sampai bagian tugas yang mana, }\end{array}$ & + \\
\hline $\begin{array}{l}\text { Pemberian respon } \\
\text { yang tidak sesuai }\end{array}$ & $\begin{array}{l}\text { Siswa memberikan respon yang tidak sesuai dengan } \\
\text { permintaan konfirmasi, pernyataan, atau pertanyaan }\end{array}$ & $\mathrm{X}$ \\
\hline
\end{tabular}

(diadaptasi dari DeJarnette \& González, 2015)

Tabel 2. Pedoman Pemosisian

\begin{tabular}{|l|l|}
\hline \multicolumn{1}{|c|}{ Posisi } & \multicolumn{1}{c|}{ Pedoman } \\
\hline Ahli & $\begin{array}{l}\text { Siswa sering melakukan gerakan K1, Siswa sesekali melakukan gerakan K2, Siswa } \\
\text { sering melakukan gerakan K2r, Siswa sering melakukan gerakan dK1, Siswa sesekali } \\
\text { melakukan gerakan A1, Siswa sering melakukan gerakan dA1 }\end{array}$ \\
\hline $\begin{array}{l}\text { Ahli yang } \\
\text { tertunda }\end{array}$ & $\begin{array}{l}\text { Siswa sesekali melakukan gerakan K1, Siswa sering melakukan gerakan K2, Siswa } \\
\text { sering melakukan gerakan K2, Siswa sering melakukan gerakan K2r }\end{array}$ \\
\hline Pemula & $\begin{array}{l}\text { Siswa sering melakukan gerakan K2, Siswa sering melakukan gerakan? Siswa sering } \\
\text { melakukan gerakan X }\end{array}$ \\
\hline Fasilitator & Siswa yang sering melakukan gerakan A1, A2, dan + \\
\hline
\end{tabular}

\section{HASIL DAN DISKUSI}

Penugasan siswa secara berkelompok bertujuan untuk mendapatkan informasi terkait dengan interaksi yang terjadi pada saat proses diskusi. Bagian Hasil menjelaskan bagaimana siswa melakukan pertukaran pengetahuan dan pertukaran tindakan. Siswa melakukan berbagai gerakan pada saat berinteraksi. Penelitian ini terfokus pada pergerakan yang dilakukan dengan tujuan untuk melakukan pertukaran pengetahuan dan pertukaran tindakan. Sehingga, ringkasan informasi disajikan pada Tabel 4 hanya menyajikan prosentase untuk gerakan K1, K2, A1, A2 dan Ch saja. Kelompok 1 melakukan 57 pertukaran, Kelompok 2 melakukan 53 pertukaran dan kelompok 3 melakukan 23 pertukaran. Proses interaksi masing-masing kelompok juga diuraikan secara lebih rinci. Selain itu, bagian Hasil menjelaskan bagaimana masing-masing siswa melakukan lagkah negosiasi dan pertukaran posisi melalui percakapan mereka. Berikut ini ringkasan informasi terkait dengan banyaknya pertukaran pengetahuan, pertukaran tindakan dan lamanya berdiskusi yang terjadi pada masing-masing kelompok disajikan pada Tabel 3.

Tabel 3. Distibusi frekuensi banyaknya pertukaran dan lamanya bediskusi masing-masing kelompok

\begin{tabular}{|c|c|c|c|}
\hline Kelompok & Pertukaran pengetahuan & Pertukaran tindakan & Lamanya berdiskusi \\
\hline 1 & 31 & 2 & 36 menit \\
\hline 2 & 26 & 7 & 38 menit \\
\hline 3 & 19 & 1 & 25 menit \\
\hline
\end{tabular}


Tabel 4. Distribusi Frekuensi Gerakan K1, K2, A1, A2, dan Ch untuk Masing-masing Anggota Kelompok

\begin{tabular}{|c|c|c|c|c|c|c|}
\hline Kel. & Anggota Kelompok & K1 & K2 & A1 & A2 & Ch \\
\hline \multirow{4}{*}{1} & S56 & $8,6 \%$ & $1,7 \%$ & $0,0 \%$ & $1,7 \%$ & $8,6 \%$ \\
\cline { 2 - 7 } & S26 & $1,7 \%$ & $0,0 \%$ & $0,0 \%$ & $0,0 \%$ & $3,4 \%$ \\
\cline { 2 - 7 } & S33 & $3,4 \%$ & $3,5 \%$ & $0,0 \%$ & $0,0 \%$ & $1,7 \%$ \\
\cline { 2 - 7 } & S25 & $3,4 \%$ & $5,2 \%$ & $0,0 \%$ & $0,0 \%$ & $3,4 \%$ \\
\hline \multirow{4}{*}{2} & S00 & $0,0 \%$ & $1,7 \%$ & $0,0 \%$ & $0,0 \%$ & $1,7 \%$ \\
\cline { 2 - 7 } & S54 & $5,7 \%$ & $3,8 \%$ & $0,0 \%$ & $0,0 \%$ & $0,0 \%$ \\
\cline { 2 - 7 } & S86 & $1,9 \%$ & $1,9 \%$ & $0,0 \%$ & $0,0 \%$ & $0,0 \%$ \\
\cline { 2 - 7 } & S02 & $5,7 \%$ & $1,9 \%$ & $0,0 \%$ & $0,0 \%$ & $0,0 \%$ \\
\hline \multirow{4}{*}{3} & S88 & $0,0 \%$ & $0,0 \%$ & $0,0 \%$ & $0,0 \%$ & $1,9 \%$ \\
\cline { 2 - 7 } & S75 & $9,4 \%$ & $0,0 \%$ & $0,0 \%$ & $7,5 \%$ & $0,0 \%$ \\
\cline { 2 - 7 } & S51 & $13,1 \%$ & $0,0 \%$ & $0,0 \%$ & $0,0 \%$ & $0,0 \%$ \\
\cline { 2 - 7 } & S18 & $0,0 \%$ & $0,0 \%$ & $0,0 \%$ & $0,0 \%$ & $0,0 \%$ \\
\cline { 2 - 7 } & S60 & $0,0 \%$ & $0,0 \%$ & $0,0 \%$ & $0,0 \%$ & $0,0 \%$ \\
\cline { 2 - 7 } & S61 & $21,8 \%$ & $0,0 \%$ & $0,0 \%$ & $0,0 \%$ & $4,3 \%$ \\
\hline
\end{tabular}

\section{Kelompok 1}

Siswa memulai percakapan pada pukul 07.50. Tiga menit pertama siswa bercakap-cakap diluar objek penugasan. Pada menit keempat guru menegur siswa untuk mulai berdiskusi terkait dengan objek penugasan. Kemudian, S56 mengajak teman-temannya untuk mulai berdiskusi. Akhirnya diskusi terkait objek penugasan dimulai pukul 08.01. Berikut ini cuplikan percakapan siswa Kelompok 1 pada grup whatsapp disajikan pada Gambar 2.

S56 dikategorikan sebagai ahli, S00, S26, S33 sebagai pemula, dan S25 sebagai ahli yang tertunda. Secara keseluruhan, S56 melakukan tantangan sebanyak lima kali, S26 dua kali dan S00, S25, S33 masingmasing sebanyak satu kali. Ilustrasi arah tantangan disajikan pada Gambar 3 sebagai berikut.

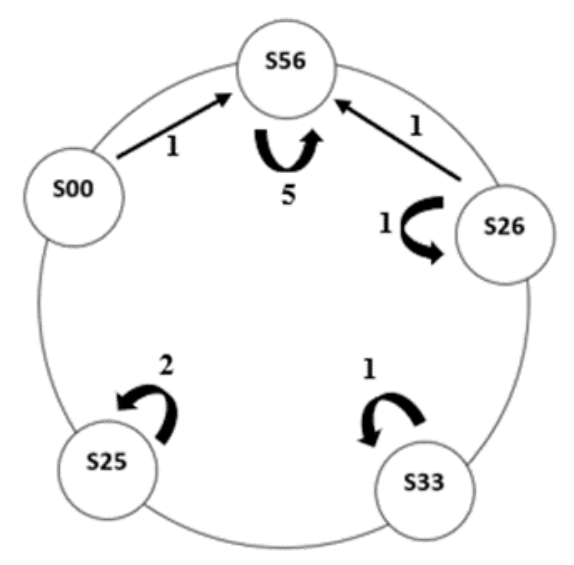

Keterangan:

- Lingkaran besar sebagai simbol putaran percakapan yang terjadi dalam satu kelompok

- Lingkaran kecil sebagai simbol siswa yang tergabung dalam putaran percakapan kelompok

- Huruf dan angka sebagai simbol identitas masing-masing siswa (dua angka yang digunakan mewakili dua digit terakhir nomor whatsapp siswa, dan s yaitu siswa. Contoh: S56 berarti siswa yang memiliki nomor whatsapp dua digit terakhirnya adalah 56)

- Panah satu arah sebagai simbol arah tantangan diberikan

- Panah berbelok sebagai simbol tantangan untuk diri sendiri,

- Angka di dekat panah sebagai simbol banyaknya tantangan yang diberikan,

Gambar 3. Ilustrasi Arah Tantanan pada Proses Diskusi Kelompok 1 
S56 mengawali percakapan dengan melakukan gerakan K1 kemudian diikuti dengan tantangan diri. S56 melakukan tantangan diri paling banyak diantara teman-temannya. Dapat dilihat pada Tabel 4, bahwa S56 melakukan gerakan K1 sama banyaknya ketika S56 melakukan gerakan Ch. Meskipun demikian, tidak setiap gerakan K1 diikuti oleh gerakan Ch. Pada saat S56 melakukan gerakan K1, S26 merespon dengan mengajukan tantangan. S26 meminta pembuktian atau penjelasan dari informasi yang diberikan S56. Akan tetapi S56 tidak langsung merespon tantangan S26. Dengan demikian S26 mencoba untuk menemukan sendiri jawaban dari rasa ngin tahunya. Hal tersebut diungkapkan S26 dengan melakukan gerakan K1 dan diikuti oleh tantangan diri. S56 memberikan respon dengan melakukan gerakan rCh. S26, S25 dan S00 merespon dengan melakukan gerakan K2r. Gerakan K2r dilakukan oleh S26, S25, dan S00 dalam rangka menerima kepeputusan S56 tanpa adanya tanggapan.

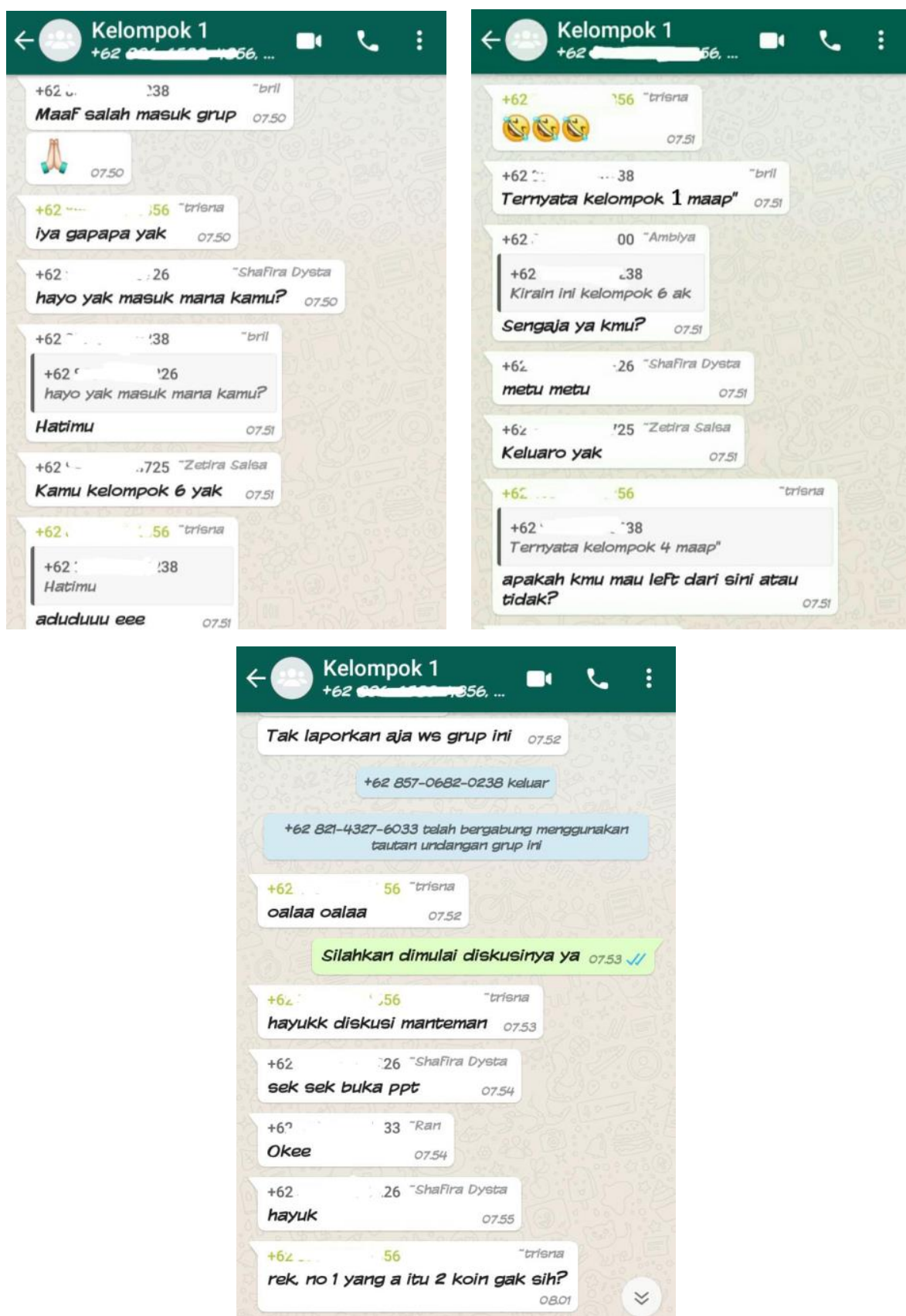

Gambar 2 Tangkapan Layar pada Grup Whatsapp Percakapan Siswa Kelompok 1 
Berdasarkan uraian situasi tersebut, peneliti menjumpai situasi yang berbeda. S33 melakukan gerakan K2 kemudian secara bersama-sama S25 dan S56 merespon dengan melakukan gerakan yang berbeda. S25 melakukan gerakan K1 sedangkan S56 melakukan gerakan A2. S56 meminta S33 untuk menunggu dan merekomendasikan diri untuk mengerjakan suatu tugas. Empat menit telah berlalu, S56 tidak memberikan berita terkait permintaan tunggu yang telah diutarakan. Akhirnya S25 mengirimkan pesan dengan melakukan gerakan K2 dan diikuti dengan gerakan dK1. Tampaknya S25 sedang menunggu konfirmasi S56 dari saran yang diajukan S25. Tidak lama kemudian S56 membalas pesan dengan gerakan K1. Setelah itu tidak ada percakapan lebih lanjut terkait saran yang diajukan S25.

Tabel 5. Distibusi frekuensi banyaknya objek yang didiskusikan

\begin{tabular}{|l|c|c|c|}
\hline & Sumber daya & Operasi & Produk \\
\hline Kelompok 1 & 10 & 6 & 21 \\
\hline
\end{tabular}

Berdasarkan Tabel 5, Kelompok 1 paling sering berdiskusi terkait dengan produk. Kata tanya yang sering diutarakan siswa Kelompok 1 adalah 'bagaimana'. Seperti contoh pesan yang dikirimkan oleh S33 tertulis yang C bagaimana? dan yang nomer 3 itu bagaimana?. Pertanyaan tersebut membutuhkan jawaban yang kompleks terkait sumberdaya, operasi, hingga menghasilkan suatu produk yang diinginkan. Sehingga, pertanyaan tersebut tidak dapat dikategorikan ke dalam salah satu objek sumberdaya, operasi, ataupun produk.

\section{Kelompok 2}

Siswa memulai percakapan pada pukul 07.48. Salah satu siswa membuka percakapan dengan salam sapa, tetapi tidak ada satu pun siswa yang memberikan respon. Tiga menit berlalu, siswa belum memulai berdiskusi. Guru khawatir siswa berdiskusi di luar grup, sehingga guru mengingatkan siswa untuk tidak berdiskusi di luar grup yang telah ditentukan oleh guru. Akhirnya diskusi kelompok dimulai pukul 07.54.

S75 dikategorkan sebagai ahli, S02 dan S54 sebagai ahli yang tertunda, S88 dan S86 sebagai pemula. Diskusi yang terjadi pada kelompok 2 berbeda dengan diskusi yang terjadi pada kelompok 1 . Gerakan tantangan yang terjadi hanya satu kali dan dilakukan oleh S75. Arah gerakan tantangan seperti yang tampak pada Gambar 4 .
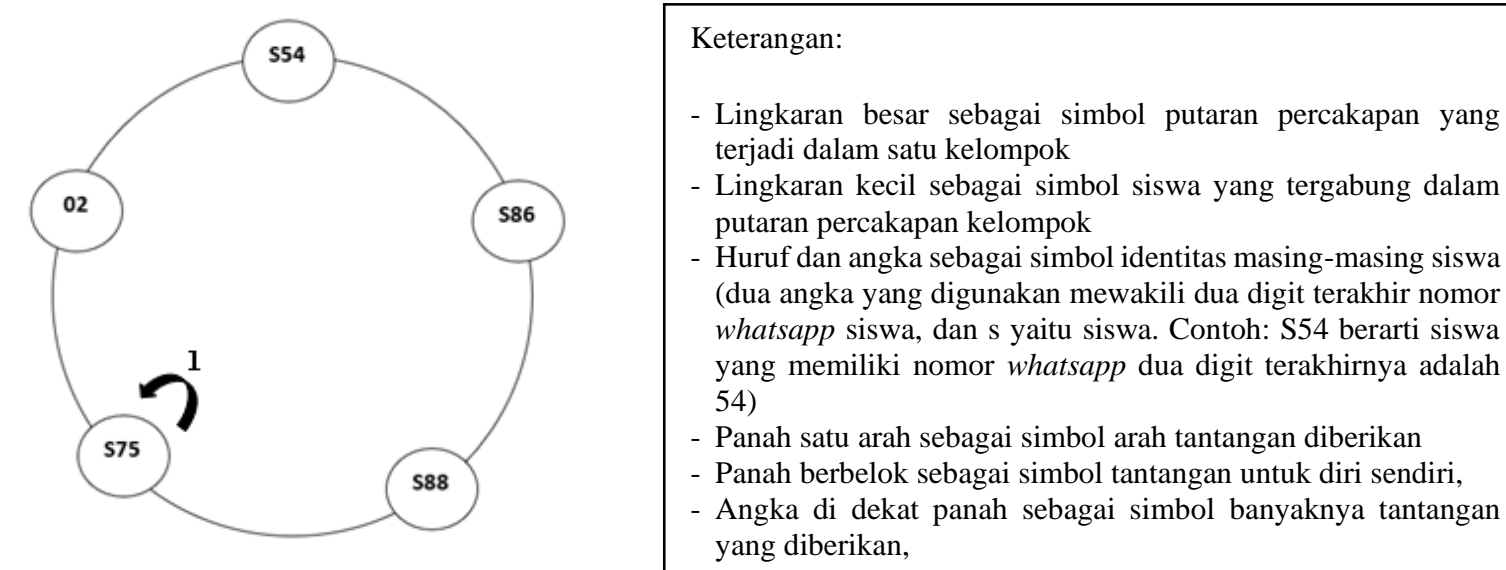

- Huruf dan angka sebagai simbol identitas masing-masing siswa (dua angka yang digunakan mewakili dua digit terakhir nomor whatsapp siswa, dan s yaitu siswa. Contoh: S54 berarti siswa yang memiliki nomor whatsapp dua digit terakhirnya adalah 54)

- Panah satu arah sebagai simbol arah tantangan diberikan

- Panah berbelok sebagai simbol tantangan untuk diri sendiri,

- Angka di dekat panah sebagai simbol banyaknya tantangan yang diberikan,

Gambar 4. Ilustrasi Arah Tantangan pada Proses Diskusi Kelompok 2 
S75 adalah siswa yang paling banyak melakukan gerakan K1 dan siswa satu-satunya yang melakukan gerakan A2. Sebagian besar gerakan K1 dilakukan dalam rangka untuk memberikan informasi dari pertanyaan yang telah diajukan siswa lain. Selain itu, S75 termasuk siswa yang tanggap. Sebagian besar pesan grup yang masuk, S75 sering menjadi siswa tercepat dalam memberikan respon. Dapat dilihat pada Tabel 4, bahwa selisih prosentase frekuensi gerakan K1 dan A2 yang dilakukan oleh S75 cukup kecil. S75 melakukan gerakan A2 sebagian besar untuk meminta temannya mengutarakan pendapat. Dengan demikian, diskusi dapat berlangsung dengan baik meskipun ada siswa yang pasif.

Frekuensi gerakan K1 yang dilakukan oleh S54 sama frekuensi gerakan K1 yang dilakukan oleh S02. S54 dan S02 melakukan gerakan K1 setelah S75. Informasi yang diberikan oleh S54 tidak lebih lengkap dari informasi yang diberikan oleh S75. Meskipun demikian pada suatu situasi tertentu bahwa S02 memberikan pertanyaan khusus yang ditujukan kepada S54. Percakapan S02 dan S54 tampak seperti kutipan berikut ini. S02: Kamu yang A berapa?

S54: 0,85

S02: oke, sama. kalau yang $B 85$ ?

S54: bukan, tapi 850

Berdasarkan kutipan percakapan tesebut, S02 memposisikan S54 sebagai ahli. S02 bertanya kepada S54 dan meminta keputusan S54 dari produk yang dihasilkan oleh S02. Pertanyaan tersebut ditujukan kepada S54 dengan cara mengutip pesan sebelumnya yang dikirimkan oleh S54. Sehingga, jelas bahwa pesan tersebut ditujukan kepada S54. Meskipun demikian, S75 juga ikut memberikan respon. S75 melakukan gerakan K2r. Hal tersebut berarti bahwa S75 menyetujui kebenaran dari informasi yang diajukan.

Tabel 6. Distibusi frekuensi banyaknya objek yang didiskusikan

\begin{tabular}{|l|c|c|c|}
\hline & Sumber daya & Operasi & Produk \\
\hline Kelompok 2 & 25 & 6 & 11 \\
\hline
\end{tabular}

Berdasarkan Tabel 6, objek yang paling sering menjadi topik diskusi adalah sumber daya. Siswa melakukan gerakan K2 dalam rangka meminta informasi. Setelah itu siswa saling mengirim pesan dan bercakap-cakap terkait dengan sumber daya yang diperlukan untuk menghasilkan produk. Sesekali siswa bertanya terkait dengan operasi. Proses tersebut berlangsung hingga didapatkan suatu produk.

\section{Kelompok 3}

Kelompok 3 memulai percakapan lebih lambat dari Kelompok 1 dan Kelompok 2. Guru memberikan arahan agar siswa segera memulai diskusi dan tidak berdiskusi di luar grup whatsapp yang telah ditentukan. Siswa memulai percakapan pada pukul 08.08.

S51 dan S61 dikategorikan sebagai ahli, S71 dan S60 sebagai ahli yang tertunda sedangkan S18 tidak termasuk dalam salah satu kategori apapun. S18 tidak dapat dikategorikan sebagai ahli, pemula, atau fasilitator karena S18 tidak pernah mengirimkan pesan apapun selama proses diskusi. Gerakan tantangan yang terjadi pada kelompok 3 hanya satu kali, dapat dilihat pada Gambar 5 berikut ini. 


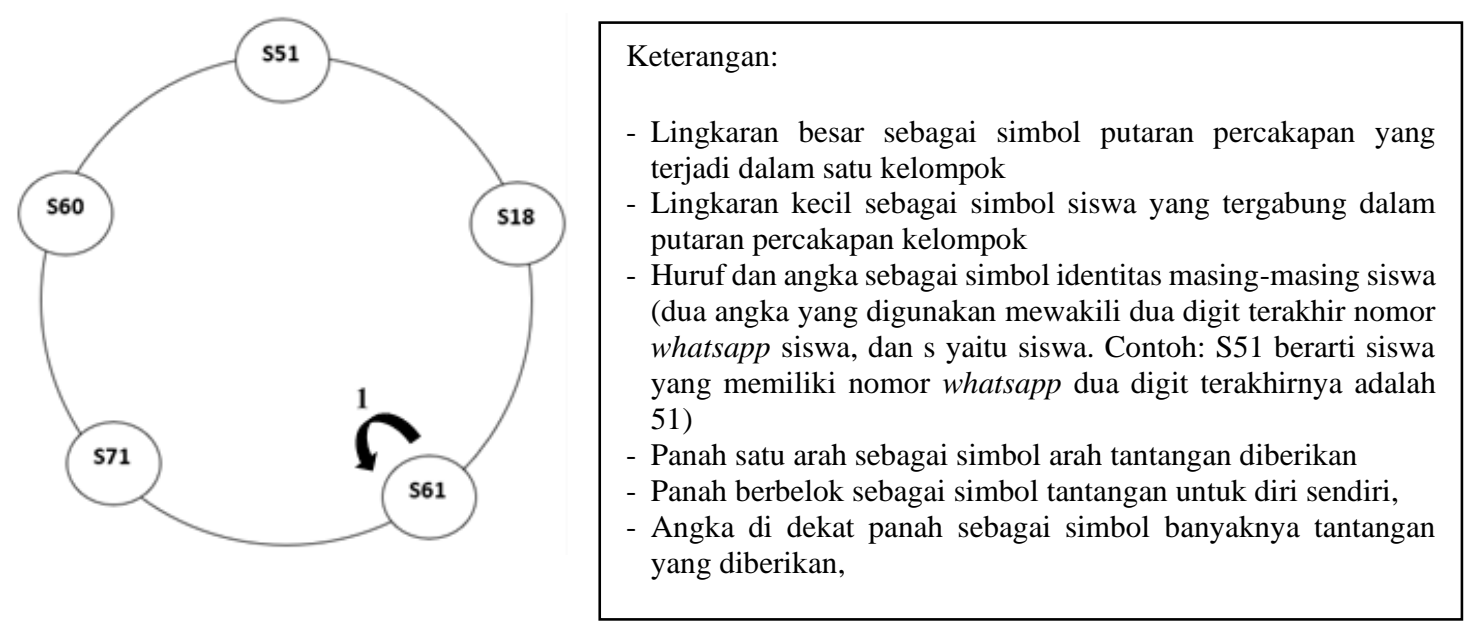

Gambar 5. Ilustrasi Arah Tantangan pada Proses Diskusi Kelompok 3

Kelompok 3 melakukan pertukaran paling sedikit. S61 melakukan gerakan K1 paling banyak. Berdasarkan Tabel 4 bahwa S18 dan S60 sama-sama tidak pernah melakukan gerakan K1, K2, A1, dan A2, tetapi posisi mereka berbeda. S18 tidak pernah mengirimkan pesan selama proses diskusi sehingga tidak bisa dikategorikan sebagai posisi mana pun. Sedangkan, S60 melakukan gerakan dK1, K2r, dan rClq. S60 tidak pernah mengajukan pernyataan berupa informasi yang dapat dikategorikan sebagai gerakan K1. Akan tetapi S60 melakukan gerakan $\mathrm{dK} 1$ dengan prosesntase paling besar diantara temannya yaitu 8,7\%. Berdasarkan Tabel 1, gerakan dK1 dilakukan pada saat siswa meminta konfirmasi dari saran yang diajukan. Dengan demikian, S60 mempunyai suatu informasi yang disarankan, akan tetapi S60 tidak meyakini nilai kebenaran dari informasi tersebut. Sehingga, S60 perlu meminta konfirmasi orang lain. berikut ini cuplikan percakapan S60 dengan siswa lain pada Kelompok 3.

S60: yang 1 jawabanya 2/4 ta?

S51: iya

S60: kalau $2 b$ itu 2/12 ta?

S61: iya

Tabel 7. Distibusi Frekuensi Banyaknya Objek yang Didiskusikan

\begin{tabular}{|l|c|c|c|}
\hline & Sumber daya & Operasi & Produk \\
\hline Kelompok 3 & 9 & 0 & 11 \\
\hline
\end{tabular}

Kelompok 3 paling sering berdiskusi terkait produk. Gerakan dK1 sering dilakukan untuk meminta keputusan orang lain dari saran yang diajukan. Berdasarkan hasil penelitian, terdapat perbedaan banyaknya pertukaran yang terjadi antara pembelajaran daring dan pembelajaran tatap muka. Seperti pada penelitian terdahulu, rata-rata pertukaran yang dihasilkan pada diskusi pembelajaran tatap muka yaitu 91 (DeJarnette \& González, 2015). Sedangkan, rata-rata pertukaran yang dihasilkan pada penelitian ini adalah 44. Rata-rata waktu yang digunakan kelompok untuk berdiskusi adalah 33 menit. Kelompok 1 melakukan pertukaran paling banyak dan Kelompok 3 melakukan pertukaran paling sedikit. Kelompok 3 melakukan pertukaran paling sedikit disebabkan oleh siswa yang lebih memilih untuk bekerja secara individu. Sebagaimana yang tampak pada Tabel 7, bahwa objek yang paling banyak didiskusikan adalah produk. Selain itu, teridentifikasi bahwa adanya dua ahli 
pada kelompok 3, yaitu S51 dan S61. Ruang diskusi daring digunakan untuk meminta keputusan siswa lain dari hasil pekerjaannya. Siswa saling mencocokkan produk yang dihasilkan. Sehingga, waktu yang digunakan Kelompok 3 berdiskusi juga paling sedikit. Situasi tersebut berbeda dengan interaksi yang terjadi pada pembelajaran tatap muka (DeJarnette \& González, 2015). Rata-rata waktu yang digunakan kelompok untuk berdiskusi yaitu 32 menit 57 detik dengan banyaknya pertukaran paling sedikit adalah 30 dan paling banyak adalah 136. Kelompok yang mengalami pertukaran paling sedikit disebabkan oleh guru yang menghabiskan banyak waktu di kelompok tersebut. Guru mendampingi dan mengontrol kinerja masing-masing kelompok pada diskusi pembelajaran tatap muka. Pada penelitian ini guru tidak mendampingi dan mengontrol kinerja siswa pada pembelajaran daring. Guru hanya mengingatkan siswa untuk segera mulai berdiskusi. Guru lebih direkomendasikan untuk menerapkan pembelajaran yang interaktif pada pembelajaran tatap muka (Katiambo et al., 2019). Dengan waktu yang hampir sama, pembelajaran daring dan pembelajaran tatap muka menghasilkan total banyaknya pergerakan yang berbeda. Banyaknya pergerakan pada pembelajaran daring kurang dari banyaknya pergerakan pada pembelajaran tatap muka. Padahal, partisipasi siswa pada pembelajaran matematika sangat penting untuk pemahaman konseptual (Hunter \& Anthony, 2014).

Siswa ahli pada masing-masing kelompok dapat diidentifikasi degan jelas. Siswa ahli sering membuat pernyataan dan memberikan informasi tanpa diikuti dengan permintaan konfirmasi kepada siswa lain. Siswa ahli tidak hanya melakukan 1 gerakan saja (K1), tetapi juga melakukan gerakan yang lain. Seperti halnya yang terjadi pada Siswa ahli kelompok 2, bahwa S75 juga melakukan gerakan A2. Gerakan A2 yang dilakukan oleh S75 sebagian besar bertujuan untuk mengajak siswa lain berpendapat terkait dengan gerakan K1 yang telah dilakukan. Sehingga, S75 lebih tepat dikategorikan sebagai ahli. Berbeda dengan kelompok 1 dan 2, ada 2 ahli pada kelompok 3 yaitu S51 dan S61. S61 melakukan gerakan K1 8,7\% lebih banyak dari S51. Meskipun demikian, S51 juga termasuk dalam kategori ahli. S51 memulai percakapan dengan gerakan melakukan dK1. S51 sesekali melakukan gerakan dA1 kemudian dilanjutkan dengan K1. S51 juga memberikan respon kepada siswa yang mengajukan pertanyaan atau meminta keputusan dari saran yang diajukan. Selain itu S51 tidak pernah melakukan gerakan K2. Hal tersebut sedikit berbeda dengan hasil penelitian (DeJarnette \& González, 2015), ada satu kelompok yang siswanya secara konsisten tidak bisa diposisikan sebagai ahli. Gerakan K1 hampir dilakukan oleh sebagian besar siswa dengan prosesntase yang cukup besar.

Kejadian yang sering muncul dalam proses diskusi pembelajaran matematika daring yaitu siswa meminta konfirmasi dari saran yang diajukan (dK1). Pada penelitian ini, siswa tersebut dikategorikan sebagai ahli yang tertunda. Siswa tersebut sudah mempunyai informasi, tetapi perlu konfirmasi siswa lain untuk memastikan nilai kebenaran dari informasi yang didapatkan.

Dari hasil pengamatan peneliti menemukan bahwa tidak ada siswa yang secara konsisten dapat dikategorikan sebagai fasilitator. Gerakan A2 hanya dilakukan oleh S56 (Kelompok 1) dan S75 (Kelompok 3). Gerakan A2 yang dilakukan oleh S75 sebagian besar untuk mendukung gerakan K1 yang dilakukan sebelumnya. Sedangkan S56 melakukan gerakan A2 untuk menanyakan siswa lain sudah atau belum melakukan suatu tugas. Jadi, kedua siswa tersebut lebih tepat dikategorikan sebagai ahli. Selain selain itu, 
gerakan A1 tidak dapat diidentifikasi dengan jelas. Hal tersebut terjadi pada pembelajaran yang dilakukan secara daring. Siswa terindentifikasi melakukan suatu tindakan dengan adanya gerakan dA1. Siswa tersebut menyatakan bahwa dia merekomendasikan suatu pekerjaan untuk dilakukan. Tetapi, tidak dapat dipastikan tindakan apa yang dia lakukan. Hal tersebut berbeda dengan situasi yang tampak pada pembelajaran tatap muka. Meskipun tidak ada pernyataan siswa fasilitator, tetapi dapt diuraikan dengan jelas tindakan yang dilakukan siswa dan dapat dikategorikan sebagai fasilitator (DeJarnette \& González, 2015).

Penelti juga menemukan bahwa keterbatasan keterampilan komunikasi siswa pada pembelajaran matematika secara daring muncul pada proses diskusi. Seperti yang tampak pada cuplikan percakapan siswa sebagai berikut.

S86: Intinya gini aja, jawabannya apa?

S75: kalau saya $(G, G)$, cuma 1

S88: Saya tidak paham.

\section{S54: Peluang dan kejadian itu beda}

Berdasarkan cuplikan percakapan tersebut, bahwa S86 menegaskan terkait produk yang dihasilkan dari percakapan sebelumnya. Hal itu mengindikasikan bahwa S86 tidak dapat menginterpretasi dengan baik percakapan yang telah terjadi. Setelah S75 memberikan respon dari pesan yang dikirimkan S86, S88 memperjelas bahwa S88 tidak paham. Kemudian S54 memberikan penjelasan singkat seperti pada cuplikan percakapan. Dengan demikian, diskusi pada pembelajaran daring memaksa siswa tidak hanya mempunyai pengetahuan yang cukup, tetapi juga keterampilan komunikasi yang baik. Diskusi memungkinkan siswa untuk meningkatkan keterampilan komunikasi (Shaughnessy, Chance, \& Kranendonk, 2009). Dalam hal ini, siswa kurag terampil dalam diskusi pembelajaran matematika secara daring. Hal tersebut mengakibatkan pembelajaran daring menjadi tidak efektif dibandingkan dengan pembelajaran tatap muka terkait dengan klarifikasi, penawaran penjelasan, dan interpretasi (Arkorful \& Abaidoo, 2015).

\section{KESIMPULAN}

Interaksi siswa pada aktivitas diskusi dalam pembelajaran matematika daring dapat berjalan dengan baik, tetapi partisipasi siswa kurang maksimal. Meskipun durasi waktu yang digunakan untuk diskusi daring hampir sama dengan durasi waktu yang digunakan pada diskusi tatap muka, banyaknya pergerakan yang diasilkan tidak sama. Banyaknya pergerakan yang dihasilkan pada diskusi daring lebih sedikit dari pada banyaknya gerakan yang dihasilkan pada diskusi tatap muka. Siswa kurang terampil dalam berkomunikasi pada diskusi pembelajaran matematika daring.

Siswa ahli dan pemula dapat diidentifikasi dengan jelas. Tindakan yang dilakukan siswa tidak dapat diidentifikasi dengan jelas dan sedikit siswa yang meminta siswa lain untuk melakukan tindakan. Selain itu, sedikit pula siswa yang melakukan kontrol aktivitas diskusi. Sehingga, siswa fasilitator tidak dapat dikategorikan secara konsisten pada diskusi pembelajaran matematika secara daring.

Berdasarkan arah tantangan, interaksi dapat dikelompokkan dalam dua bentuk. Yang pertama bentuk kompleks dan yang kedua bentuk sederhana. Bentuk kompleks terdiri dari dua arah tantangan yaitu tantangan 
diri sendiri dan tantangan kepada orang lain. Bentuk sederhana terdiri dari satu arah saja yaitu tantangan diri sendiri.

Penelitian ini masih ada yang kurang baik yaitu partisipasi siswa. Partisipasi siswa kurang tampak menyababkan pertukaran yang terjadi kurang optimal. Dengan demikian, perlu adanya stimulus untuk menumbuhkan partisipasi siswa pada interaksi dalam pembelajaran matematika daring. Selain itu, peneliti merekomendasikan penelitian berikutnya untuk menganalisis lebih mendalam terkait dengan peningkatan partisipasi siswa dalam beriteraksi pada pembelajaran daring melalui pembelajaran kreatif dan inovatif. Hal-hal perlu diidentifikasi yaitu peningkatan banyaknya gerakan yang dilakukan masing-masing siswa dalam kelompok dan peningkatan berbagai jenis gerakan yang dilakukan. Sehingga, tujuan pembelajaran diharapkan dapat tercapai secara maksimal dengan adaya peningkatan interaksi antar siswa yang terjadi pada pembelajaran matematika daring.

\section{UCAPAN TERIMA KASIH}

Peneliti mengucapkan terima kasih kepada Kepala Sekolah SMAN 1 Giri Banyuwangi. Peneliti telah diberikan kesempatan untuk melaksanakan penelitian dalam rangka untuk menyusun karya ilmiah ini. Tidak lupa juga peneliti mengucapkan terima kasih kepada Dr. Subanji, M.Si. dan Dr. Sisworo, M.Si yang telah membimbing peneliti hingga dapat terselesaikannya artikel ilmiah ini. Selain itu, peneliti juga mengucapkan terima kasih kepada semua pihak yang tidak dapat disebutkan satu per satu. Terima kasih atas bantuan dan dukungan teman-teman semua sehingga penelitian dapat terselesaikan hingga menjadi artikel ilmiah ini.

\section{REFERENSI}

Aji, R. H. S. (2020). Dampak Covid-19 pada Pendidikan di Indonesia: Sekolah, Keterampilan, dan Proses Pembelajaran. SALAM: Jurnal Sosial Dan Budaya Syar-I, 7(5). Retrieved from https://doi.org/10.15408/sjsbs.v7i5.15314

Annur, M. F., \& Hermansyah. (2020). Analisis Kesulitan Mahasiswa Pendidikan Matematika Dalam Pembelajaran Daring Pada Masa Pandemi Covid-19. Jurnal Kajian, Pnelitian Dan Pengembangan Kependidikan, 11, 195-201.

Apriliyanto, B., Saputro, D. R. S., \& Riyadi. (2018). Student's social interaction in mathematics learning. Journal of Physics: Conference Series, 983(1), 1-6. Retrieved from https://doi.org/10.1088/17426596/983/1/012130

Arkorful, V., \& Abaidoo, N. (2015). The role of e-learning, advantages and disadvantages of its adoption in higher education. International Journal of Instructional Technology and Distance Learning, 12(1), $29-42$.

Azmitia, M. (1988). Peer Interaction and Problem Solving: When Are Two Heads Better Than One? Child Development, 59(1), 87-96. Retrieved from https://doi.org/10.2307/1130391

Cobb, P., Stephan, M., McClain, K., \& Gravemeijer, K. (2001). Participating in classroom mathematical 
practices. Journal of the Learning Sciences, 10(1-2), 113-163. Retrieved from https://doi.org/10.1207/S15327809JLS10-1-2_6

Cobb, P., Yackel, E., \& Wood, T. (1992). Interaction and learning in mathematics classroom situations. Educational Studies in Mathematics, 23(1), 99-122. Retrieved from https://doi.org/10.1007/BF00302315

DeJarnette, A. F., \& González, G. (2015). Positioning during group work on a novel task in Algebra II. Journal for Research in Mathematics Education, 46(4), 378-422. Retrieved from https://doi.org/10.5951/jresematheduc.46.4.0378

Francis, M. K., Wormington, S. V., \& Hulleman, C. (2019). The Costs of Online Learning: Examining Differences in Motivation and Academic Outcomes in Online and Face-to-Face Community College Developmental Mathematics Courses. Frontiers in Psychology, 10(September), 1-12. Retrieved from https://doi.org/10.3389/fpsyg.2019.02054

Giatman, M., Siswati, S., \& Basri, I. Y. (2020). Online Learning Quality Control in the Pandemic Covid19 Era in Indonesia. Journal of Nonformal Education, 6(2), 168-175. Retrieved from https://journal.unnes.ac.id/nju/index.php/jne

Handarini, O. I., \& Wulandari, S. S. (2020). Pembelajaran Daring sebagai Upaya Study From Home (SFH) selama Pandemi Covid 19. Jurnal Pendidikan Administrasi Perkantoran (JPAP), 8(3), 496-503.

Herbel-Eisenmann, B. A., Wagner, D., Johnson, K. R., Suh, H., \& Figueras, H. (2015). Positioning in mathematics education: revelations on an imported theory. Educational Studies in Mathematics, 89(2), 185-204. Retrieved from https://doi.org/10.1007/s10649-014-9588-5

Hunter, R., \& Anthony, G. (2014). Small Group Interactions: Opportunities for Mathematical Learning, 3(36), 361-368.

Katiambo, D., Mutsotso, S. N., \& Wasike, D. W. (2019). Classroom Interaction Patterns a nd Students' Learning Outcomes in Secondary School Mathematics in Kenya, 8(9), 1405-1409.

Kementerian Pendidikan dan Kebudayaan. (2020). Pedoman Penyelenggaraan Belajar Dari Rumah Dalam Masa Darurat Penyebaran Corona Virus Disease (Covid-19). Surat Edaran Nomor 15 Tahun $2 O 2 O$. Indonesia.

Kusumaningrum, B., \& Wijayanto, Z. (2020). Apakah Pembelajaran Matematika Secara Daring Efektif? (Studi Kasus pada Pembelajaran Selama Masa Pandemi Covid-19). Kreano, Jurnal Matematika Kreatif-Inovatif, $\quad 11(2), \quad 139-146 . \quad$ Retrieved from https://journal.unnes.ac.id/nju/index.php/kreano/article/view/25029

McVee, M. B., Silvestri, K. N., Barrett, N., \& Haq, K. S. (2019). Positioning Theory. Theoretical Models and Processes of Literacy, (February 2020), 381-400. Retrieved from https://doi.org/10.4324/9781315110592-23

Mulenga, E. M., \& Marbán, J. M. (2020). Prospective teachers' online learning mathematics activities in the age of COVID-19: A cluster analysis approach. Eurasia Journal of Mathematics, Science and Technology Education, 16(9). Retrieved from https://doi.org/10.29333/EJMSTE/8345 
Mustakim, M. (2020). Efektivitas Pembelajaran Daring Menggunakan Media Online Selama Pandemi Covid-19 Pada Mata Pelajaran Matematika. Al Asma : Journal of Islamic Education, 2(1), 1. Retrieved from https://doi.org/10.24252/asma.v2i1.13646

Pusat Bahasa. (2008). Kamus Bahasa Indonesia. Jakarta: Pusat Bahasa Departemen Pendidikan Nasional.

Shaughnessy, J. M., Chance, B., \& Kranendonk, H. (2009). Focus in High School Mathematics : Reasoning and Sense Making in Statistics and Probability. Reston: VA: NCTM.

Turner, J. H. (1988). A Theory of Social Interaction. Social Forces. Stanford: Stanford University Press. Retrieved from https://doi.org/10.2307/2579266

Wiryanto. (2020). Proses Pembelajaran Matematika Di Sekolah Dasar Di Tengah Pandemi Covid-19. Jurnal Review Pendidikan Dasar: Jurnal Kajian Pendidikan Dan Hasil Penelitian, 6(2), 125-132.

Zelle, G. (2009). Exploring the application of positioning theory to the analysis of organisational change. Australian and New Zealand Academy of Management Conference, (December), 1-15. 